\title{
Correction to: Replication in Rock Art Past and Present: a Case Study of Bronze and Iron Age Rock Art in the Altai, Eastern Eurasia
}

\section{Rebecca O'Sullivan ${ }^{1}$}

Published online: 27 June 2020

(C) Springer Science+Business Media, LLC, part of Springer Nature 2020

\section{Correction to: Journal of Archaeological Method and Theory (2020) https://doi.org/10.1007/s10816-020-09460-z}

Due to a typesetting mistake, the images of Figs. 3 to 11 did not match their captions. The original version has been corrected.

Publisher's Note Springer Nature remains neutral with regard to jurisdictional claims in published maps and institutional affiliations.

The online version of the original article can be found at https://doi.org/10.1007/s10816-020-09460-z

Rebecca O'Sullivan

rebecca@jlu.edu.cn; https://orcid.org/0000-0001-9413-1746

1 School of Archaeology, Jilin University, 2699 Qianjin Street, Changchun 130012 Jilin, China 